\title{
Studies on phosphorus requirement of lentil and French bean intercropping with Indian mustard
}

\author{
R. K. SINGH AND M. K. SINGH
}

MEMBERS OF RESEARCH FORUM:

Corresponding author :

R.K. SINGH, Krishi Vigyan Kendra,

Rura Mallu, Jalaun (U.P.) INDIA

Email: rajansnikumbh@gmail.com

Co-authors :

M. K. SINGH, C.S. Azad University of Agriculture and Technology, KANPUR (U.P.) INDIA
Received : 10.10.2017; Revised : 22.11.2017; Accepted : 30.11 .2017

\section{Summary}

The study was laidout during Rabi season of 1994-95 and 1995-96 at Student's instructional Farm, C.S. Azad university of Agriculture and technology, Kanpur. The soil of experimental field was sandy loam, having low fertility status. Five cropping systems i.e., Indian mustard sole, Indian mustard + lentil, Indian mustard without lentil at same distance, Indian mustard + French bean and Indian mustard without French bean at same distance were tested under three levels of phosphorus (control, $30 \mathrm{~kg} \mathrm{P}_{2} \mathrm{O}_{5} / \mathrm{ha}$ and $60 \mathrm{~kg} \mathrm{P}_{2} \mathrm{O}_{5} / \mathrm{ha}$ ). the highest yield of Indian mustard by $24.04 \mathrm{q} / \mathrm{ha}$ was harvested under treatment of Indian mustard sole. In associated cropping system of lentil and French bean, Indian mustard yielded by $11.72 \mathrm{q} / \mathrm{ha}$ and $15.00 \mathrm{q} / \mathrm{ha}$ seed yield, respectively. The yield of Indian mustard was obtained $16.95 \mathrm{q} / \mathrm{ha}$ at $30 \mathrm{~kg} \mathrm{P} \mathrm{O}_{5} /$ ha closely followed by $60 \mathrm{~kg} \mathrm{P}_{2} \mathrm{O}_{5} / \mathrm{ha}(16.45 \mathrm{q} / \mathrm{ha})$. the growth and yield traits of Indian mustard were concordant to the yields obtained from Indian mustard under different cropping systems and levels of phosphorus. The yield of intercropped lentil and French bean were harvested by $6.69 \mathrm{q} / \mathrm{ha}$ and $12.02 \mathrm{q} / \mathrm{ha}$, respectively. Both inter crops provided more granin yield upto highest tested dose of $60 \mathrm{~kg} \mathrm{P}_{2} \mathrm{O}_{5} /$ ha closely followed by $30 \mathrm{~kg} \mathrm{P}_{2} \mathrm{O}_{5} / \mathrm{ha}$. The growth and yield fruits of both crops were commensurable to the yields obtained from lentil and French bean under cropping systems with Indian mustard and levels of phosphorus application.

Key words : Associated cropping, Commensurable, Concordant, French bean, Inter cropping

How to cite this article : Singh, R.K. and Singh, M.K. (2017). Studies on phosphorus requirement of lentil and French bean intercropping with Indian mustard. Asian J. Soil Sci., 12 (2) : 349-354 : DOI : 10.15740/HAS/AJSS/12.2/349-354. 